\title{
Proline content of sugar beet storage roots: Response to water deficit and nitrogen fertilization at field conditions
}

\author{
J.A. Monreal ${ }^{\text {a }}$, E.T. Jiménez ${ }^{\text {a }}$, E. Remesal ${ }^{\text {a }}$, R. Morillo-Velarde ${ }^{\text {b }}$, \\ S. García-Mauriño ${ }^{a, *}$, C. Echevarría ${ }^{a}$ \\ a Departamento de Biología Vegetal y Ecología, Facultad de Biología, Universidad de Sevilla, \\ Avenida Reina Mercedes No. 6, 41012 Seville, Spain \\ b AIMCRA (Asociación de Investigación para la Mejora del Cultivo de la Remolacha Azucarera), \\ Delegación Sur, c/ Metalurgia No. 36, 41080 Seville, Spain
}

Received 18 August 2006; accepted 21 November 2006

\begin{abstract}
Drought stress is one of the major factors causing profit loss of the sugar beet crop. The accumulation of proline, an indicator of water stress, has been reported in response to osmotic and salt stress in sugar beet leaves, but there is little information about its levels in storage roots. Proline in storage roots is potentially useful as indicator of situations that lead to decreased yield and quality of the root, such as drought stress and excess nitrogen. This study has been focused towards proline quantification in storage roots from field trials concerning irrigation, sugar beet variety and nitrogen fertilization. Water deficit is the main factor leading to proline accumulation in sugar beet roots. Excess $\mathrm{N}$ supply also increases proline levels, partially by increasing leaf area index (LAI) and exacerbating drought stress. The two varieties studied (Claudia and Ramona) had different responses to water shortage and to nitrogen. Maximum proline levels were measured in Claudia roots subjected to a combination of water shortage and excess N. A positive and significant correlation was found between proline and glucose levels in sugar beet roots, pointing to a relationship between stress responses, carbohydrate catabolism, and proline and glucose accumulation. This proposal was supported by the effect of treatments with di-1-p-menthene (anti-transpirant) and with DMDP (2,5-dihydroxymethyl-3,4-dihydroxypyrrolidina, a glycosidase inhibitor), which lead to decreased level of proline in non-irrigated Claudia sugar beet roots.
\end{abstract}

(c) 2006 Elsevier B.V. All rights reserved.

Keywords: Drought stress; Glucose; Proline; Sugar beet

\section{Introduction}

Water deficit in leaf tissue affects many physiological processes, ultimately reducing yield. Drought stress is the one of the major factors causing profit loss of the sugar beet crop (Pidgeon et al., 2001; Tognetti et al., 2003). In subtropical latitudes (southern Mediterranean countries, northern African countries), sugar beet is sown in autumn and harvested in summer; therefore, crops are reaching maturity for harvest when temperatures and evaporative demands are at the highest. This fact impacts on sugar production, decreasing yield and increasing the accumulation

\footnotetext{
Abbreviations: fw, fresh weight; LAI, leaf area index; S.E.standard error

* Corresponding author at: Departamento de Biología Vegetal y Ecología, Sección de Fisiología Vegetal, Facultad de Biología, Universidad de Sevilla, Avenida Reina Mercedes No. 6, 41012 Seville, Spain.

Tel.: +34 95 4557074/9924; fax: +34 95 4615780/559945.

E-mail address: sgarma@us.es (S. García-Mauriño).
}

of soluble non-sucrose compounds. These compounds, such as proline and glucose, impair the crystallization of sugar in the factory process and lead to the formation of colored components, thus diminishing the industrial quality of the root (Campbell, 2002; Coca et al., 2004).

Proline appears to be the most widely distributed metabolite accumulated under stress conditions (Delauney and Verma, 1993). The increase of proline concentration in response to water deficit is a well-documented fact (Hanson et al., 1977; Ferreira et al., 1979; Hasegawa et al., 1994; Yeo, 1998), and a large body of data indicates a positive correlation between proline accumulation and enhanced tolerance to drought and salt stress (Van Rensburg and Krüger, 1994; Kishor et al., 1995). Other experimental evidence suggests that proline accumulation is a symptom of stress injury rather than an indicator of stress tolerance (Liu and Zhu, 1997). Nevertheless, proline accumulation seems to be a useful index of drought stress in plants (Iannucci et al., 2000; Ain-Lhout et al., 2001). 
Nitrogen is the most important element of those supplied to sugar beet. Nitrogen deficiency causes a reduction in growth rate and a delay in the initiation of storage processes (Marschner, 1995). On the other hand, excess nitrogen can also have a detrimental effect on sugar beet: excessive or late nitrogen applications may result in decreased sucrose yield and quality (Anderson and Peterson, 1988; Pocock et al., 1990). Increased proline levels in response to supply with excess nitrogen have been reported (Delauney et al., 1993).

Leaves of plants are the major site of proline synthesis. Gzik (1996) reported increased proline levels in sugar beet leaves in response to osmotic and salt stress. In addition, a direct correlation between the degree of stress and proline content pointed up that proline accumulation was a useful stress-indicator in sugar beets. On the contrary, there is scarce information concerning proline levels in sugar beet storage roots, although proline is known to accumulate in roots of other species in response to drought stress (Raymond and Smirnoff, 2002; Demiral and Türkan, 2005). The hypothesis tested was that the same factors which trigger proline accumulation in leaves (drought stress and excess $\mathrm{N}$ ) lead to proline accumulation in roots. Therefore, this study has been focused towards the quantification of proline levels of autumn sown sugar beet storage roots subjected to various field trials concerning irrigation, sugar beet variety (two varieties with potentially different stress response and stress tolerance), and nitrogen fertilization. Proline accumulation in sugar beet storage roots has two different features: first as stress indicator, and second as a nitrogen compound that diminishes the quality of the root. Both stressful conditions and excess $\mathrm{N}$ lead to mobilization of stored carbohydrates to supply for energy and carbon skeletons to synthesize stress molecules and $\mathrm{N}$ containing substances, diminishing sucrose yield and decreasing the quality of the root. Glucose could build up as a remainder of sucrose catabolism. Its content has been measured in order to explore a relationship with proline accumulation in sugar beet roots.

\section{Materials and methods}

\subsection{Plant material and growth conditions}

Commercial varieties of sugar beet (Beta vulgaris L., Claudia and Ramona, KWS, Germany) were supplied by AIMCRA (Asociación de Investigación para la Mejora del Cultivo de la Remolacha Azucarera) from field trials in four consecutive seasons: $1999 / 2000,2000 / 2001,2001 / 2002$, and 2002/2003. The seasons are identified by the year of the harvest throughout this work. Trials were conducted at locations near to Seville (Southern Spain), except for one trial in 2000 (El Puerto de Santa María, Cadiz, Southern Spain). The records of maximum and minimum temperature, total rainfall and irrigation for the four seasons studied (data from RIA: Red de Información Agroclimática de Andalucía, Consejería de Agricultura y Pesca de la Junta de Andalucía, Spain) are summarized in Fig. 1. Details of the irrigation and $\mathrm{N}$ fertilization trials are summarized in Table 1.

Sugar beets were sown in autumn (October-November) and harvested in the following summer, except for one trial in 2002.
Autumn sugar beet was sown on 15 November 2001 and harvested during the following summer. Spring sugar beet was sown on 27 February 2002 and harvested at the end of the following autumn. The records of maximum and minimum temperature, total rainfall and irrigation at harvest time are shown in Table 2 (data from RIA).

\subsection{Pre-harvest treatments}

\subsubsection{Trials 1 and 2}

Claudia sugar beets were treated with an anti-transpirant (di1- $p$-menthene, Vapor Gard, Miller Chemical and Fertilizer Co., USA) to reduce moisture loss. Two trials were performed in two different locations of Seville (Southern Spain). Plants were treated $\left(2.51 \mathrm{ha}^{-1}\right)$ on 15 May and 13 June, and harvested on 21 July 2003.

\subsubsection{Trial 3}

Non-irrigated Claudia plants were treated with the pyrrolidine alkaloid 2,5-dihydroxymethyl-3,4-dihydroxypyrrolidina (DMDP, Calbiochem, La Jolla, CA, USA), in order to block carbohydrate mobilization during the stress response. Alkaloids mimicking the structure of monosaccharide inhibit glycosidases because of a structural resemblance to the sugar moiety of the natural substrate (Asano et al., 2000). DMDP was sprayed at $120 \mathrm{mM} 2$ weeks, 1 week and 1 day before sampling nonirrigated Claudia sugar beets on 11 August 2003.

\subsection{Proline determination}

At each sampling date, plants were harvested and samples were prepared following their arrival to the laboratory. Each sample consisted of sections from at least three different storage roots. For each experimental condition, the roots were washed, divided into small pieces with an electric mincer, mixed thoroughly, distributed in several portions $(25 \mathrm{~g})$ and stored at $-35^{\circ} \mathrm{C}$.

Proline was quantified by the acid-ninhydrin procedure of Bates et al. (1973). Root samples $(0.5 \mathrm{~g})$ were ground with $3 \%$ sulphosalicylic acid $(10 \mathrm{ml})$ and clarified by centrifugation. Supernatant $(2 \mathrm{ml})$ was mixed with the same volume of acidninhydrin and acetic acid, the mixture was oven incubated at $100^{\circ} \mathrm{C}$ for $1 \mathrm{~h}$, and the reaction was finished in an ice bath. The reaction mixture was extracted with toluene $(4 \mathrm{ml})$ and absorbance was read at $517 \mathrm{~nm}$, using toluene as a blank. The proline concentration was determined from a standard curve and calculated on a fresh weight basis. Two replicates were measured for each sample, and mean values are displayed.

\subsection{Glucose determination}

The concentration of glucose was determined in root samples with the Glucose (HK) Assay Kit from Sigma (St. Louis, MO, USA). This kit is for the quantitative enzymatic determination of glucose. Glucose is phosphorylated by adenosine triphosphate in the reaction catalyzed by hexokinase. Glucose-6-phosphate 



SAMPLING DATE

Fig. 1. Average weekly maximum and minimum temperature, total rainfall and irrigation for the locations of the field trials (2000-2003). A: Aznalcázar (Sevilla); B: El Puerto de Santa María (Cádiz); C and D: Alcalá del Río (Sevilla); E: Carmona (Sevilla).

is then oxidized to 6-phosphogluconate in the presence of oxidized nicotinamide adenine dinucleotide (NAD) in a reaction catalyzed by glucose-6-phosphate dehydrogenase. During this oxidation, an equimolar amount of NAD is reduced to NADH. The consequent increase in absorbance at $340 \mathrm{~nm}$ is directly proportional to glucose concentration.

\subsection{Determination of nitrogen in plant}

The measurements of $\mathrm{N}$ in plants were performed by AIMCRA making use of irrigated Claudia plants from the $\mathrm{N}$ fertilization trials in 2001-2003. Plants corresponding to one lineal meter (three replicates, five plants per replicate) were divided in leaves, petioles, crowns and roots. Total $\mathrm{N}$ was determined with a micro-kjeldahl method (Bilbao et al., 1999) in represen- tative dried samples from each part of the plant and referred to the whole weight. Data are presented as the $\mathrm{kg}$ of $\mathrm{N}$ corresponding to the plants harvested from 1 ha.

The maximum $\mathrm{N}$ content in plants from May to June was used to classify the trials into three groups (Table 3 ). Mean values for each group were: $\mathrm{N} 1: 227 \mathrm{~kg} \mathrm{ha}^{-1}$; N2: $308 \mathrm{~kg} \mathrm{ha}^{-1}$; N3: $503 \mathrm{~kg} \mathrm{ha}^{-1}$.

\subsection{Measurement of leaf area index (LAI)}

Leaf area index (LAI) is defined as the total leaf area of a crop per unit area of soil surface $\left(\mathrm{m}^{2} \mathrm{~m}^{-2}\right)$. A direct destructive method has been used to estimate LAI.

Plants corresponding to $0.5 \mathrm{~m}^{2}$ of soil surface were harvested. The harvested foliage tissue was subsampled (five 
Table 1

Details of the field trials (irrigation and $\mathrm{N}$ fertilization) from which sugar beets have been analyzed in four consecutive seasons

\begin{tabular}{|c|c|c|c|c|}
\hline Trial & Location & Variety & Irrigation $\left(1 \mathrm{~m}^{-2}\right)$ & Nitrogen $\left(\mathrm{kg} \mathrm{ha}^{-1}\right)$ \\
\hline \multirow[t]{2}{*}{ Irrigation } & Aznalcázar, Sevilla & Claudia & 539 & RN (150) \\
\hline & Puerto de Santa María, Cádiz & Claudia & 0 & RN (122) \\
\hline \multicolumn{5}{|l|}{2001} \\
\hline \multirow[t]{2}{*}{$\mathrm{N}$ fertilization } & Alcalá del Río, Sevilla & Claudia & 470 & RN (150) \\
\hline & Alcalá del Río, Sevilla & Claudia & 470 & $\mathrm{EN}(450)$ \\
\hline \multirow{2}{*}{ Irrigation } & Alcalá del Río, Sevilla & Ramona & 470 & RN (150) \\
\hline & Alcalá del Río, Sevilla & Ramona & 0 & $\mathrm{RN}(150)$ \\
\hline \multicolumn{5}{|l|}{2002} \\
\hline \multirow[t]{2}{*}{$\mathrm{N}$ fertilization } & Alcalá del Río, Sevilla & Claudia & 450 & WN (0) \\
\hline & Alcalá del Río, Sevilla & Claudia & 450 & RN (180) \\
\hline Irrigation & Alcalá del Río, Sevilla & Ramona & 0 & $\mathrm{RN}(180)$ \\
\hline \multicolumn{5}{|l|}{2003} \\
\hline \multirow[t]{3}{*}{$\mathrm{N}$ fertilization } & Carmona, Sevilla & Claudia & 658 & WN (0) \\
\hline & Carmona, Sevilla & Claudia & 658 & 1/2 RN (90) \\
\hline & Carmona, Sevilla & Claudia & 658 & RN (180) \\
\hline \multirow[t]{4}{*}{ Irrigation } & Carmona, Sevilla & Claudia & 658 & RN (180) \\
\hline & Carmona, Sevilla & Claudia & 0 & RN (180) \\
\hline & Carmona, Sevilla & Ramona & 658 & RN (180) \\
\hline & Carmona, Sevilla & Ramona & 0 & RN (180) \\
\hline
\end{tabular}

The level of application of $\mathrm{N}$ within each treatment in the fertilization trials was: $\mathrm{WN}$, no $\mathrm{N}$ fertilization; $\mathrm{RN}$, recommended level; $1 / 2 \mathrm{RN}, 50 \%$ of the recommended level; EN, recommended level plus $300 \mathrm{~kg} \mathrm{ha}^{-1}$. Irrigated Claudia and Ramona sugar beets were compared with non-irrigated crops in the irrigation trials.

plants, four leaves for plant) for specific leaf area (SLA, the ratio of leaf area to dry foliage mass, $\mathrm{m}^{2} \mathrm{~kg}^{-1}$ ) determination. The leaf area was estimated from the following equation, in which $L$ is the length and $W$ is the width of the leaf:

leaf area $=14.5-2.3 L-1.3 W+0.1 L^{2}+0.2 W^{2}+0.6 W L$

The leaf area $\left(\mathrm{m}^{2}\right)$ was used to calculate the SLA $\left(\mathrm{m}^{2} \mathrm{~kg}^{-1}\right)$ of the sample, and referred to the dry weight $(\mathrm{kg})$ of the leaves

Table 2

Average maximum and minimum temperature and total rainfall at harvest time for autumn and spring sown sugar beets (2002 season)

\begin{tabular}{llcc}
\hline Date & $T_{\max }\left({ }^{\circ} \mathrm{C}\right)$ & $T_{\min }\left({ }^{\circ} \mathrm{C}\right)$ & Rainfall $(\mathrm{mm})$ \\
\hline Autumn sown sugar beet & & & \\
$\quad$ July 1-15 & 33.3 & 16.4 & 0 \\
July 16-31 & 33.9 & 17.1 & 0 \\
August 1-15 & 32.1 & 17.0 & 0 \\
August 16-31 & 31.1 & 15.8 & 0 \\
Spring sown sugar beet & & & \\
October 1-15 & 25.2 & 17.3 & 108.6 \\
October 16-31 & 25.2 & 11.6 & 0 \\
November 1-15 & 22.5 & 8.7 & 25.4 \\
November 16-31 & 16.4 & 7.3 & 7.6 \\
\hline
\end{tabular}

harvested from $0.5 \mathrm{~m}^{2}$ of soil surface. The end result is leaf area referred to soil surface (LAI, $\mathrm{m}^{2} \mathrm{~m}^{-2}$ ).

\subsection{Statistical analysis}

For comparison among treatments, data was subjected to one-way analysis of variance (ANOVA), and $t$-test, Dunn's multiple range test, Tukey test or Student-Newman-Keuls test were used to compare mean values from two groups (SigmaStat 2.03,

Table 3

Levels of applied fertilizer $\mathrm{N}$ and maximum $\mathrm{N}$ content in plants in the $\mathrm{N}$ fertilizer trials

\begin{tabular}{llcll}
\hline Year & Treatment & $\mathrm{N}$ applied $\left(\mathrm{kg} \mathrm{ha}^{-1}\right)$ & $\mathrm{N}$ in plant $\left(\mathrm{kg} \mathrm{ha}^{-1}\right)$ & Group \\
\hline 2001 & RN & 150 & 223 & $\mathrm{~N} 1$ \\
& EN & 450 & 316 & $\mathrm{~N} 2$ \\
2002 & WN & 0 & 420 & $\mathrm{~N} 3$ \\
& RN & 180 & 519 & $\mathrm{~N} 3$ \\
& EN & 480 & 569 & $\mathrm{~N} 3$ \\
2003 & WN & 0 & 209 & $\mathrm{~N} 1$ \\
& 1/2 RN & 90 & 250 & $\mathrm{~N} 1$ \\
& RN & 180 & 299 & $\mathrm{~N} 2$ \\
\hline
\end{tabular}

Mean values for each group are-N1: $227 \mathrm{~kg} \mathrm{ha}^{-1}$; N2: $308 \mathrm{~kg} \mathrm{ha}^{-1}$; N3: $503 \mathrm{~kg} \mathrm{ha}^{-1}$. 
SPSS Inc., USA). The means are considered to be significantly different at $P<0.05$.

\section{Results}

\subsection{Irrigation and variety}

The average values of proline content measured in Claudia and Ramona sugar beet roots (recorded as monthly means \pm S.E.; Fig. 2) showed differences between irrigated and non-irrigated plants and between varieties. Proline levels markedly increased from May to August, and the raise in proline content started before and reached higher values in non-irrigated plants. Maximum values were measured in non-irrigated Claudia sugar beets. Statistical analysis demonstrated significant differences between irrigated and non-irrigated Claudia from June to August; meanwhile, Ramona accumulated less proline and significant differences between irrigated and non-irrigated plants were detected only in June. When maximum LAI (leaf area index) was compared in the two varieties (Table below Fig. 2, data supplied by AIMCRA), no differences between irrigated Claudia and Ramona could be seen. When subjected to water shortage however, the lower LAI of Ramona (4.6 versus 5.6 of non-irrigated Claudia) denoted a better capacity to face up to water limitation.

The comparison of maximum and minimum temperature, total rainfall and irrigation for the four seasons studied (Fig. 1) with individual proline records (Fig. 3), revealed some characteristics of proline accumulation. The effect of temperature on proline accumulation could be seen in the trial located in Cadiz, near the sea (Figs. 1B and 3B); the relatively moderate maximum temperatures reached in this trial caused proline levels which were lower than maximum values detected in the following seasons (Fig. 3C-E). Nevertheless, water deficit was a more important factor than temperature to increase proline content in sugar beet roots; the proline levels measured in irrigated plants in the same season (Fig. 3A) were low although maximum temperature exceeded $35^{\circ} \mathrm{C}$ (Fig. 1A). In this trial, the irrigation was the highest and was supplied as late as the last date of sampling; accordingly, proline levels measured in irrigated Claudia were below the medium values recorded (Fig. 2, Claudia irrigated).

Maximum proline accumulation was detected around the end of the growth period. To determine if proline levels were associated with the stage of development or, alternatively, related to environmental factors, a field trial was conducted in 2002 with two different planting and harvest patterns on the same site (Fig. 4). Proline content was markedly higher in autumn sugar beet when compared with spring sugar beet at the time of harvest (35-40 weeks of growth). The climatic conditions at harvest time were quite different for autumn and spring sugar beets (Table 2). The high maximum temperature and inexistent rainfall when autumn sugar beet was harvested are conditions usually linked to heat and water stress. On the contrary, maximum temperature was lower, and September-October natural rainfall supplied

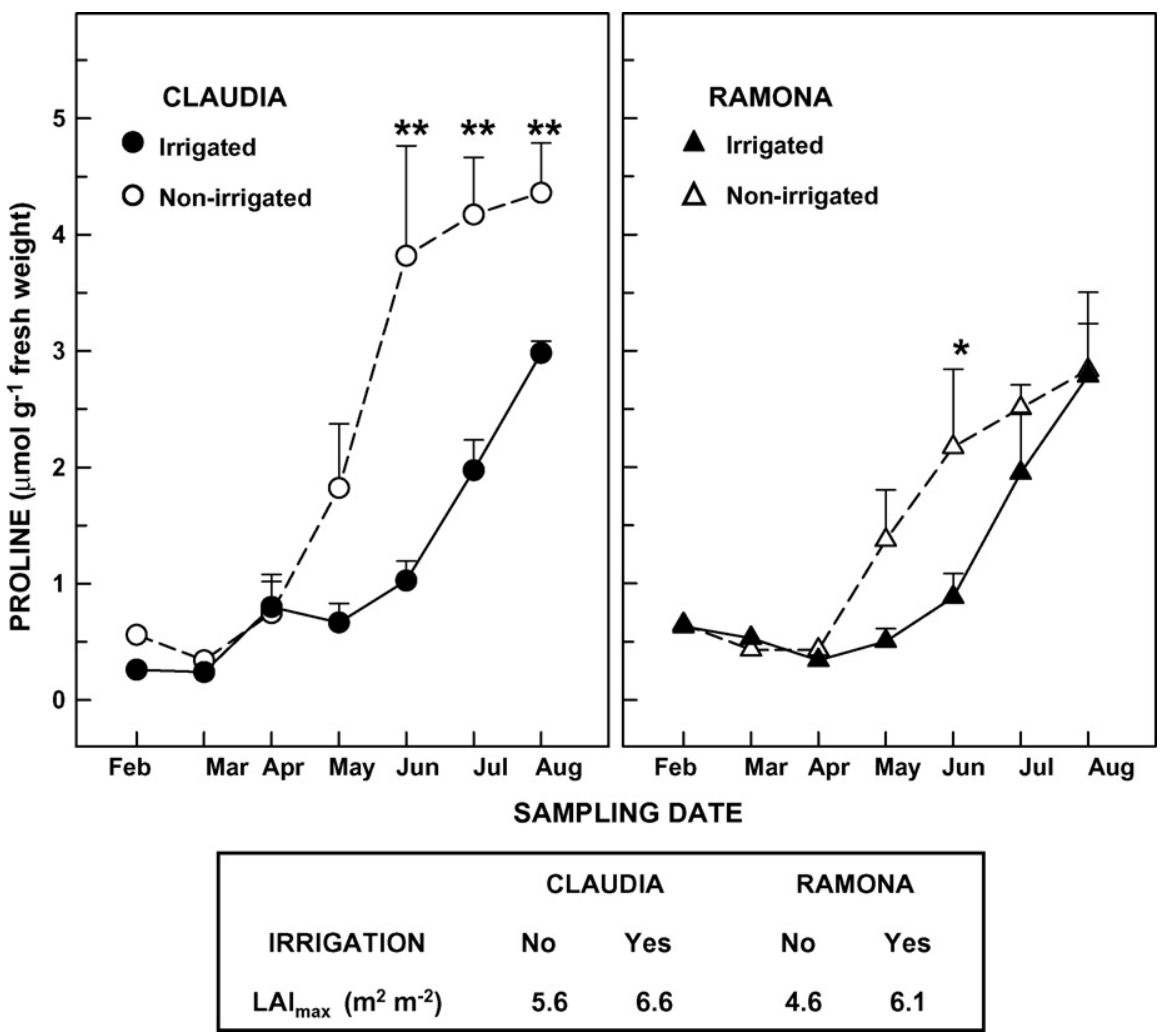

Fig. 2. Average proline content of irrigated and non-irrigated Claudia and Ramona storage roots. The data shown are monthly mean values \pm S.E. (four seasons). Comparison of proline content between non-irrigated and irrigated plants showed significant differences (level of signification: ${ }^{*} P<0.05$; ${ }^{* *} P<0.01$ vs. non-irrigated). Numbers below the figure show maximum mean leaf area index (LAI) measured during the season. 

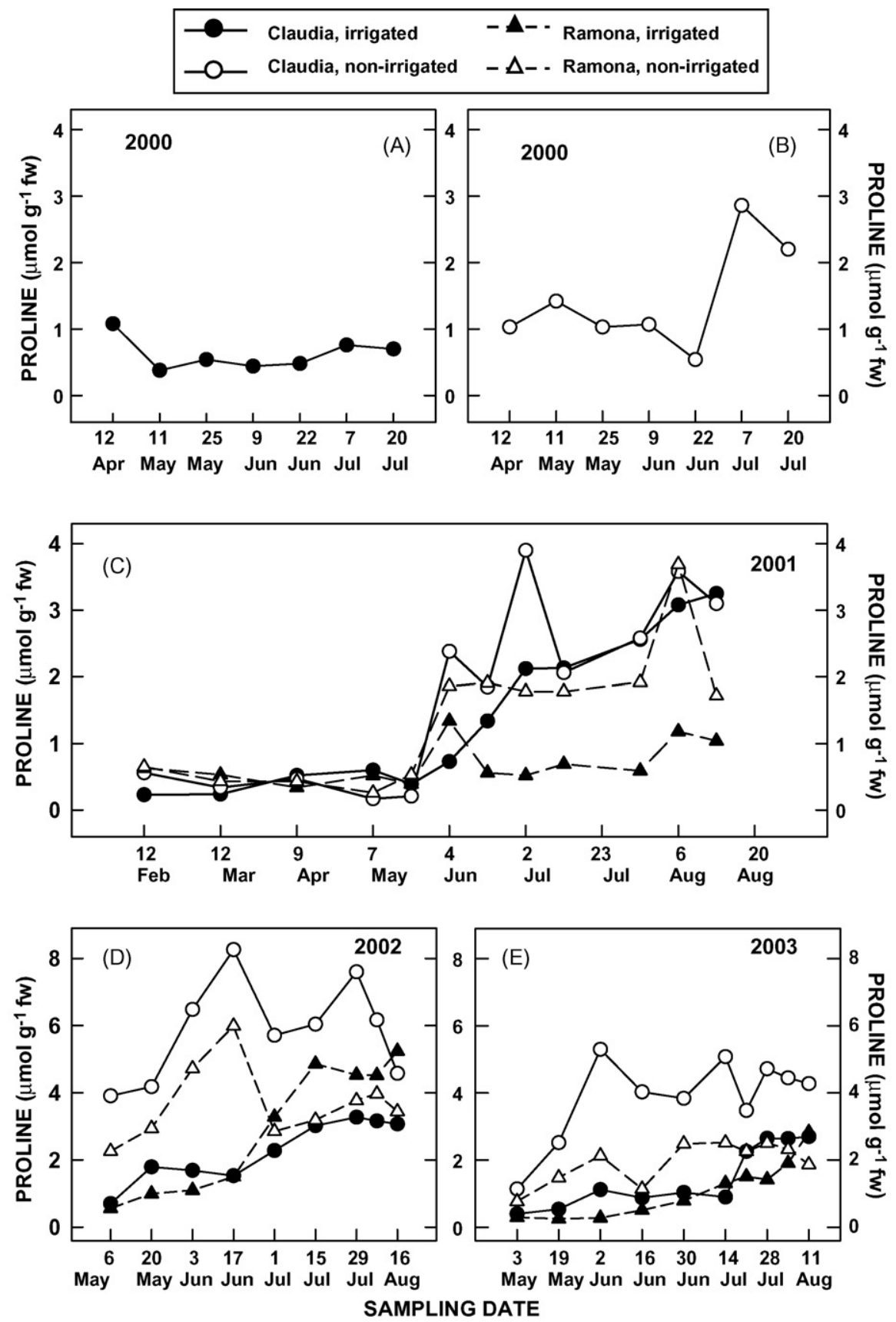

Fig. 3. Proline accumulation of sugar beet storage roots in 2000 (A and B), 2001 (C), 2002 (D) and 2003 (E) seasons.

water, when spring sugar beet was harvested. Conversely, the proline accumulated by autumn sown sugar beets of about 25 weeks (in May) was lower than the proline content of 25 weeks spring sugar beets (in August).

\subsection{Nitrogen}

In order to investigate the effects of nitrogen on proline accumulation of sugar beet roots, several trials with different levels of $\mathrm{N}$ supply (Table 1) were carried out over three growing seasons (2001-2003), and the proline content (Fig. 5) was recorded according to $\mathrm{N}$ in the plant (Table 3). Increased nitrogen in the plant significantly enhanced the proline content from May to
August (Fig. 5). Higher nitrogen in the plant was also bound up with higher LAI (numbers below Fig. 5).

The $\mathrm{N}$ content in plants was the highest in the 2002 trials (503 $\mathrm{kg} \mathrm{ha}^{-1}$; N3; Table 3). The 2001 and 2002 trials were carried out over the same location (Alcalá del Río, Seville). The abundant rainfall from February to November in 2001 (406 mm), when compared with the same period in $2002(204 \mathrm{~mm})$, could have leached soil $\mathrm{N}$ and be the reason of the lesser $\mathrm{N}$ in plants measured in 2001.

If the corresponding partners of the trials classified in the $\mathrm{N}$ groups (Ramona versus Claudia; irrigation versus water shortage) are shown separately (Fig. 6), differences between Claudia and Ramona can be inferred. The proline accumulation 




Fig. 4. Time-course of proline accumulation of roots from autumn sown and spring sown Ramona sugar beets in 2002 season.

of Claudia was highly stimulated by the lack of irrigation (Fig. 6A versus B). When compared with Claudia, proline accumulation of Ramona was enhanced to a higher degree by $\mathrm{N}$ level in plant (Fig. 6A versus $\mathrm{C}$ ). The highest records of proline were measured in Claudia when water deficit was combined with maximum $\mathrm{N}$ in plant (Fig. 6B, triangles).

\subsection{Proline and glucose}

Glucose content in sugar beet roots was recorded in samples from the field trials carried out over 2001 and 2002, and patterns of proline and glucose accumulation were compared.



\begin{tabular}{|ccc|}
\hline & $\mathrm{N}$ in plant $\left(\mathrm{kg} \mathrm{ha}^{-1}\right)$ & $\mathrm{LAI}_{\max }\left(\mathrm{m}^{2} \mathrm{~m}^{-2}\right)$ \\
$\mathrm{N} 1$ & 227 & 5.5 \\
$\mathrm{~N} 2$ & 308 & 6.0 \\
$\mathrm{~N} 3$ & 503 & 8.2 \\
\hline
\end{tabular}

Fig. 5. Proline accumulation of sugar beet storage roots according to $\mathrm{N}$ in plants. Comparison of proline content between groups (N1-N3) showed significant differences (level of signification: ${ }^{*} P<0.05 v s$. N1). Numbers below the figure show maximum mean leaf area index (LAI) measured during the season.
Table 4

Relationship between proline and glucose accumulated in sugar beet roots

\begin{tabular}{llll}
\hline Assay & Treatment & $\begin{array}{l}\text { Correlation } \\
\text { coefficient }(R)\end{array}$ & $P$-value \\
\hline Fertilization & RN & 0.846 & $<0.0001$ \\
& EN & 0.727 & $<0.0001$ \\
Irrigation, Claudia & Irrigation & 0.790 & $<0.0001$ \\
& No irrigation & 0.880 & $<0.0001$ \\
Irrigation, Ramona & Irrigation & 0.718 & $<0.0001$ \\
& No irrigation & 0.809 & $<0.0001$ \\
\hline
\end{tabular}

Glucose levels were significantly higher in Claudia than in Ramona, and the raise of glucose accumulation started in May (Fig. 7A), reaching higher values in non-irrigated Claudia sugar beets. Maximum level of glucose in roots was measured in 2002, the same season in which the highest accumulation of proline was recorded (Fig. 3D). The glucose content of the roots in the late stage of the crop increased with the amount of nitrogen measured in the plant (Fig. 7B).

Collectively, the patterns described for glucose accumulation resembled those of proline levels. The relationship between the two variables was measured with the Spearman rank order correlation test (Table 4). A high, positive and significant degree of association was found for every condition of the trials carried out in 2000-2002.

\subsection{Pre-harvest treatments}

The results presented in this paper suggest a relationship between water shortage, plant responses to water deficit, and the accumulation of glucose and proline. Table 5 shows the results of pre-harvest treatments directed to act on this sequence of events in order to modify proline accumulation in sugar beet roots. When Claudia sugar beets were treated with an anti-transpirant, the treatment increased proline content of irrigated plants (possibly due to a corresponding increase of heat stress) and decreased it in non-irrigated plants (trials 1 and 2). The treatment did not decrease the yield in any condition assayed (data supplied by AIMCRA). The treatment with the glycosidase inhibitor DMDP markedly reduced the proline content of non-irrigated Claudia sugar beets (trial 3). This result points up to a relationship between sucrose mobilization and proline synthesis.

Table 5

Effect of pre-harvest treatments on proline content of sugar beet roots

\begin{tabular}{llll}
\hline Water supply & Treatment & \multicolumn{2}{l}{ Proline $\left(\mu \mathrm{mol} \mathrm{g}^{-1} \mathrm{fw}\right)$} \\
\cline { 3 - 4 } & & Control & Treatment \\
\hline Trial 1 & & 0.98 & 2.14 \\
$\quad$ Irrigation & Dimenthene & 2.10 & 1.07 \\
$\quad$ Water shortage & Dimenthene & & \\
Trial 2 & & 2.26 & 3.11 \\
$\quad$ Irrigation & Dimenthene & 3.48 & 1.74 \\
$\quad$ Water shortage & Dimenthene & & \\
Trial 3 & & & 1.41 \\
$\quad$ Water shortage & DMDP & 4.28 & \\
\hline
\end{tabular}




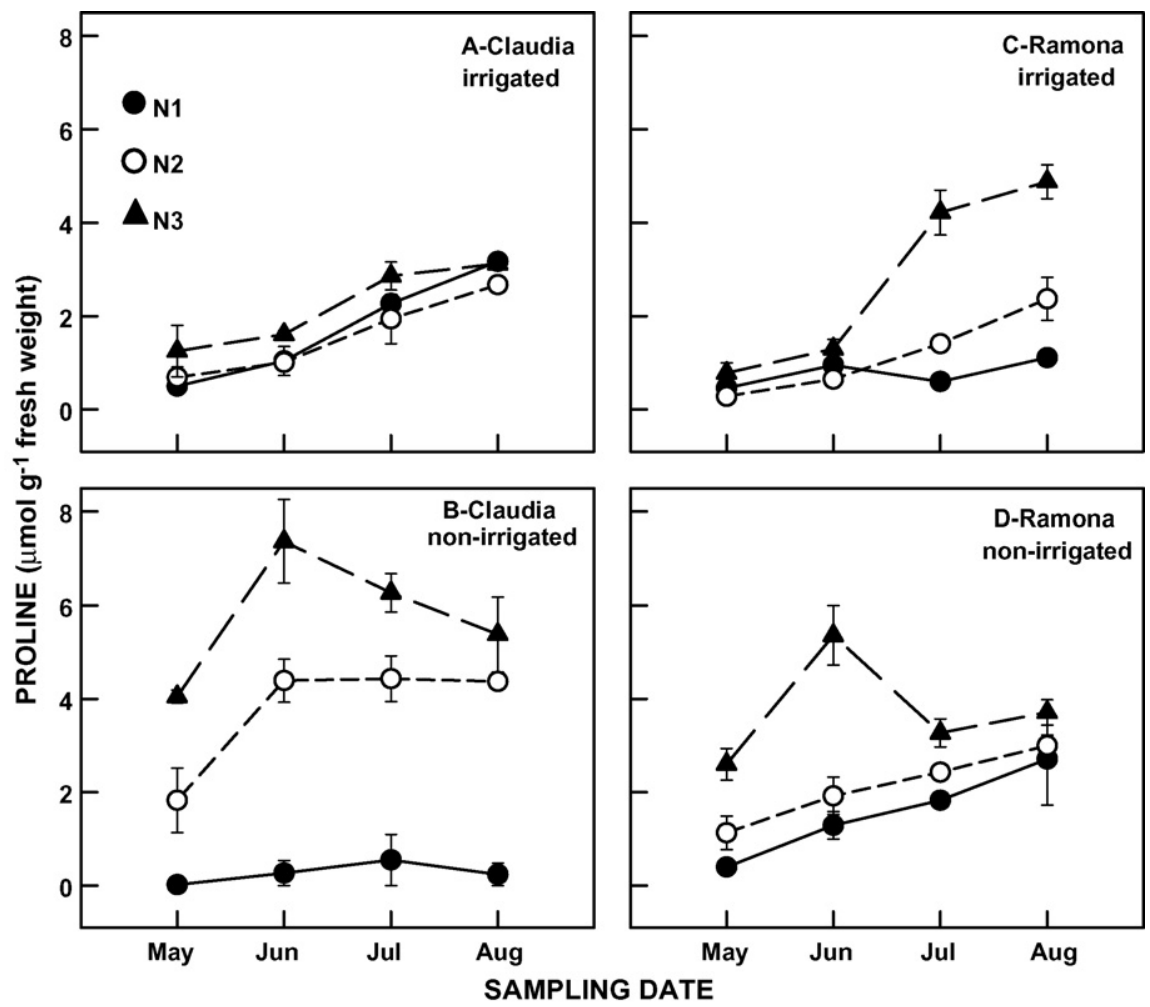

Fig. 6. Proline accumulation of sugar beet storage roots according to $\mathrm{N}$ groups, variety and irrigation. Trials were classified in $\mathrm{N}$ groups (A) and their corresponding partners (B-D) were grouped depending on variety (Claudia or Ramona) and irrigation (irrigated or non-irrigated).

\section{Discussion}

Results in this paper show that water deficit is the main factor leading to proline accumulation in sugar beet roots, as previously described in plant leaves (Hanson et al., 1977; Ferreira et al., 1979; Hasegawa et al., 1994; Yeo, 1998). Environmental factors leading to water depletion (drought, temperature extremes) are common when autumn sown sugar beet is harvested. The level of proline in roots increased after May-June, when natural rainfall is absent and maximum temperature is high. Proline levels measured in this work were always higher in non-irrigated plants (Fig. 2). Temperature modulates the degree of drought stress thus increasing proline accumulation, although water availability is the main factor leading to enhanced proline levels in roots. In fact high water supply was associated with low proline content, in spite of high temperature (Fig. 3A).

Although proline levels measured in spring and autumn sown sugar beets reveal both developmental and environmental specific features, the latter are undoubtedly of greater consequence. Plants at comparable stages of development accumulated different levels of proline in their roots depending on the date of sampling, which determinates the climatic conditions and, consequently, the degree of drought stress suffered by the plant (Fig. 4). The results also show that proline is a good index of the present stress experienced by the plant, since proline level declines following the relief of stress. The proline level of spring beets was higher in summer than in the subsequent autumn. The proline accumulated in summer could have been used to supply for nitrogen and energy requirements during the recovery of the stress (Sivaramakrishnan et al., 1988).

The two sugar beet varieties, Claudia and Ramona, accumulated different amounts of proline in roots subjected to water restriction (Fig. 2). Non-irrigated Claudia plants always contained more proline than Ramona sugar beets. Some of the differences in proline accumulation could be caused by differences in leaf area index (LAI) between the two varieties. Irrigated plants of both varieties had similar LAI and accumulated proline at the same level (Fig. 2). The lower LAI of non-irrigated Ramona was associated with a lesser content of proline in roots, and points up that this variety has a better capacity to deal with water deficit. In natural environments high values of leaf area confer high rates of growth under well-watered conditions, but also increase the risk of death during drought. Species from dry environments have an inherently low leaf area, which may ensure persistence (White et al., 2003). A causal relationship between LAI, water loss by transpiration, drought stress, and proline accumulation in roots, is supported by the effect of the treatment with the anti-transpirant di-1-p-menthene (Table 4), which, in fact, decreased the proline accumulated by non-irrigated Claudia sugar beets.

In addition to water supply, temperature and sugar beet variety, the level of proline accumulated by sugar beet roots was dependent on nitrogen incorporated to the plant (Fig. 5). Maximum proline levels recorded in this work were measured in 2002, when nitrogen in plants was the highest (Table 3). Excess $\mathrm{N}$ increases proline synthesis from ornithine (Delauney et al., 

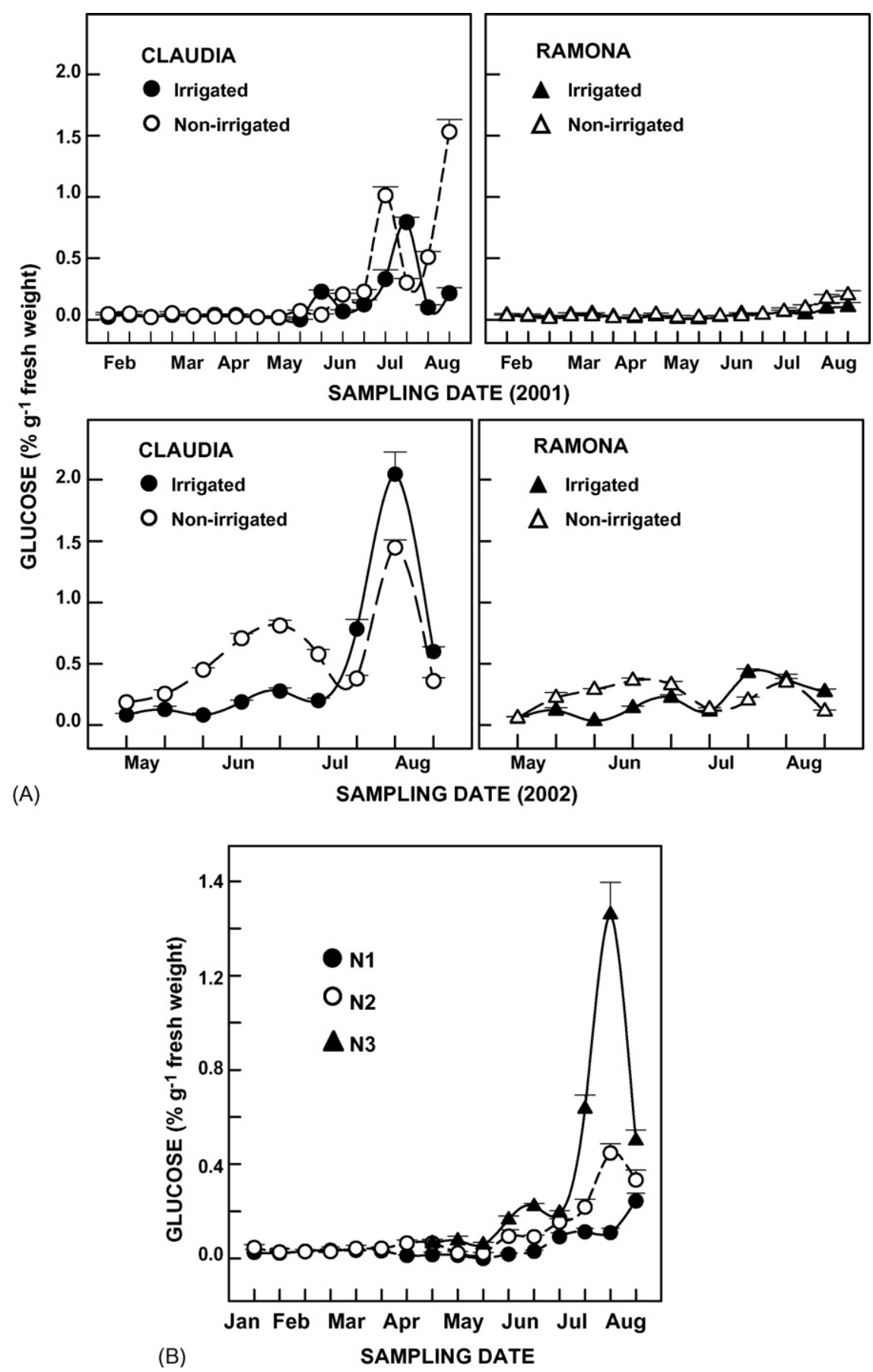

Fig. 7. Glucose accumulation of sugar beet storage roots in 2001 and 2002 seasons. A: Irrigation trials. Data are means \pm S.E. $(n=4-12)$. B: N fertilization trials. Glucose accumulation of sugar beet storage roots according to $\mathrm{N}$ in plants. Data are means \pm S.E. $(n=4-8)$. The statistical analysis revealed significant differences between the groups (N1-N3) from June to August (ANOVA, $P<0.01$ ).

1993). In addition, the synthesis of proline has been proposed to be a mean of assimilating excess ammonium, acting as an additional mode of nitrogen storage (Brugière et al., 1999). Excess $\mathrm{N}$ supply also caused an increased leaf area (table below Fig. 5). Milford et al. (1985) found a positive correlation between leaf area expansion rate and increasing nitrogen, and that the change in leaf expansion rate was lower for non-irrigated than for irrigated crops in sandy soils. Similarly, LAI increased with nitrogen application in spring sown sugar beet (Hoffmann and
Blomberg, 2004). By increasing LAI, excess $\mathrm{N}$ can augment drought stress. Maximum levels of proline in roots were measured in non-irrigated Claudia with the highest level of $\mathrm{N}$ in plant (Fig. 6B).

Drought stress causes stomata closure, limits transpiration, and increases leaf temperature as a consequence. Both stomata closure and heat stress decrease photosynthesis yield (Salvucci and Crafts-Bradner, 2004). Many tissues of stressed plants are likely to have an increased demand for rapidly metabolizable 
carbohydrate in order to initiate the responses that would guarantee stress tolerance. This must be satisfied despite a likely decrease in carbon fixation and may lead to the mobilization of carbon from storage. The mobilization of stored carbohydrates could increase the glucose content of the root as a consequence of sucrose catabolism. Glucose itself may have a role as osmolyte (Hasegawa et al., 2000). Stored carbohydrates could also be mobilized in order to synthesize proline to cope with drought stress. In this respect, the glycosidase inhibitor DMDP lowered the level of proline in sugar beet storage roots (Table 4). We have reported that autumn sown sugar beet has a full active respiratory system at the date of the harvest (García-Mauriño et al., 2005). This fact allows the metabolism of carbohydrates and the synthesis of stress molecules whenever the environmental factors promote the response.

The pattern of glucose accumulation in sugar beet roots recorded in this work resembles that of proline: the level of glucose increased in the last stage of the crop, Claudia accumulated more glucose than Ramona, and maximum accumulation corresponded to non-irrigated Claudia plants (Fig. 7A). Likewise, increased $\mathrm{N}$ content measured in plants was linked to enhanced glucose levels in the roots (Fig. 7B). A positive and statistically significant degree of correlation was found between proline and glucose levels in sugar beet roots (Table 4), signifying a relationship between drought stress and plant responses that lead to proline and glucose accumulation.

\section{Conclusion}

The results show that water shortage is the main factor leading to proline accumulation in sugar beet storage roots. Proline levels reveal the current degree of stress of the plant, which depends on water supply (rainfall and irrigation), temperature, sugar beet variety and nitrogen fertilization. The same elements are implied in glucose accumulation and decrease yield of the crop. Modifying the stress condition would lead to an increased recovery and industrial quality of the root.

\section{Acknowledgements}

The authors thank AIMCRA (Asociación de Investigación para la Mejora del Cultivo de la Remolacha Azucarera), especially to J. Martínez, for the supply of sugar beet plants from field trials performed by this society. This research was supported by the research projects FEDER IFD97-0893-CO3-01 from Subdirección General de Proyectos de Investigación Científica y Técnica of Spain, USE-MONTE P-96 from Universidad de Sevilla and Monte, and by the Junta de Andalucía (PAI group CVI 298). J.A. Monreal was in receipt of a FPI fellowship from Universidad de Sevilla (Spain). The authors also thank Christopher Roland for correction of the manuscript.

\section{References}

Ain-Lhout, F., Zunzunegui, M., Diaz-Barradas, M.C., Tirado, R., Clavijo, A., García-Novo, F., 2001. Comparison of proline accumulation in two Mediterranean shrubs subjected to natural and experimental water deficit. Plant Soil 230, 175-183.
Anderson, F.N., Peterson, G.A., 1988. Effect of incrementing nitrogen application on sucrose yield of sugarbeet. Agron. J. 80, 709-712.

Asano, N., Nash, R.J., Molyneux, R.J., Feet, G.W.J., 2000. Sugarmimic glycosidase inhibitors: natural occurrence, biological activity and prospects for therapeutic application. Tetrahedron-Asymm. 11, 1645 1680.

Bates, I.S., Waldren, R.P., Teare, J.D., 1973. Rapid determination of free proline for water stress studies. Plant Soil 39, 205-207.

Bilbao, B., Giraldo, D., Hevia, P., 1999. Quantitative determination of nitrogen content in plant tissue by a colorimetric method. Commun. Soil Sci. Plant Anal. 30, 1997-2005.

Brugière, N., Dubois, F., Limami, A.M., Lelandais, M., Roux, Y., Sangwan, R.S., Hirel, B., 1999. Glutamine synthetase in the phloem plays a major role in controlling proline production. Plant Cell 11, 1995-2011.

Campbell, L.G., 2002. Sugar beet quality improvement. J. Crop Prod. 5, 395-413.

Coca, M., García, M.T., González, G., Peña, M., García, J.A., 2004. Study of coloured components formed in sugar beet processing. Food Chem. 86, 421-433.

Delauney, A.J., Verma, D.P.S., 1993. Proline biosynthesis and osmoregulation in plants. Plant J. 4, 215-223.

Delauney, A.J., Hu, C.A., Kishor, P.B., Verma, D.P.S., 1993. Cloning of ornithine delta-aminotransferase cDNA from Vigna aconitifolia by transcomplementation in Escherichia coli and regulation of proline biosynthesis. J. Biol. Chem. 268, 18673-18678.

Demiral, T., Türkan, I., 2005. Comparative lipid peroxidation, antioxidant defense systems and proline content in roots of two rice cultivars differing in salt tolerance. Environ. Exp. Bot. 53, 247-257.

Ferreira, L.G.R., Souza, J.G., Prisco, J.F., 1979. Effects of water deficit on proline accumulation and growth of two cotton genotypes of differing drought resistance. Z. Pflanzenphysiol. 93, 189-199.

García-Mauriño, S., Jiménez, E.T., Monreal, J.A., Morillo-Velarde, R., Echevarría, C., 2005. Adenylate patterns of autumn-sown sugar beet differ from spring-sown sugar beet. Implications for root quality. Physiol. Plant. 124, 200-207.

Gzik, A., 1996. Accumulation of proline and pattern of $\alpha$-amino acids in sugar beet plants in response to osmotic, water and salt stress. Environ. Exp. Bot. 36, 29-38.

Hanson, A., Nelson, C.E., Everson, E.H., 1977. Evaluation of free proline accumulation as an index of drought resistance using two contrasting barley cultivars. Crop Sci. 17, 720-726.

Hasegawa, P.M., Bressan, R.A., Nelson, D.E., Samaras, Y., Rhodes, D., 1994. Tissue culture in the improvement of salt tolerance in plants. In: Yeo, A.R., Flowers, T.J. (Eds.), Soil Mineral Stresses. Approaches to Crop Improvement. Springer, Berlin/Heidelberg, pp. 83125.

Hasegawa, P.M., Bressan, R.A., Zhu, J.K., Bohnert, H.J., 2000. Plant cellular and molecular responses to high salinity. Annu. Rev. Plant Physiol. Plant Mol. Biol. 51, 463-499.

Hoffmann, C.M., Blomberg, M., 2004. Estimation of leaf area index of Beta vulgaris L. based on optical remote sensing data. J. Agron. Crop Sci. 190, 197-204.

Iannucci, A., Rascio, A., Russo, M., Di Fonzo, N., Martiniello, P., 2000. Physiological responses to water stress following a conditioning period in berseem clover. Plant Soil 223, 217-227.

Kishor, P.B.K., Hong, Z., Miao, G.H., Hu, C.A.A., Verma, D.P.S., 1995 Overexpression of $\Delta^{1}$-pyrroline-5-carboxylate synthetase increases proline production and confers osmotolerance in transgenic plants. Plant Physiol. 108, 1387-1394.

Liu, J., Zhu, J.K., 1997. Proline accumulation and salt-stress-induced gene expression in a salt-hypersensitive mutant of Arabidopsis. Plant Physiol 114, 591-596.

Marschner, H., 1995. Mineral Nutrition of Higher Plants, 2nd ed. Academic Press, London.

Milford, G.F.J., Pocock, T.O., Jaggard, K.W., Biscoe, P.V., Armstrong, M.J., Last, P.J., Goodman, P.J., 1985. An analysis of leaf growth in sugar beet. IV. The expansion of the leaf canopy in relation to temperature and nitrogen. Ann. Appl. Biol. 107, 335-347. 
Pidgeon, J.D., Werker, A.R., Jaggard, K.W., Richter, G.M., Lister, D.H., Jones, P.D., 2001. Climatic impact on the productivity of sugar beet in Europe, 1961-1995. Agric. For. Meteorol. 109, 27-37.

Pocock, T., Milford, G.F.J., Armstrong, M., 1990. Storage root quality in sugar beet in relation to nitrogen uptake. J. Agric. Sci. 115, 355-362.

Raymond, M.J., Smirnoff, N., 2002. Proline metabolism and transport in maize seedlings at low water potential. Ann. Bot. 89, 813-823.

Salvucci, M.E., Crafts-Bradner, S.J., 2004. Inhibition of photosynthesis by heat stress: the activation state of Rubisco as a limiting factor in photosynthesis. Physiol. Plant. 120, 179-186.

Sivaramakrishnan, S., Patell, V.Z., Flower, D.J., Peacock, J.M., 1988. Proline accumulation and nitrate reductase activity in contrasting sorghum lines mid-season drought stress. Physiol. Plant. 74, 418-426.
Tognetti, R., Palladino, M., Minnocci, A., Delfine, S., Alvino, A., 2003. The response of sugar beet to drip and low-pressure sprinkler irrigation in southern Italy. Agric. Water Manage. 1804, 1-21.

Van Rensburg, L., Krüger, G.H.J., 1994. Applicability of abscisic acid and (or) proline accumulation as selection criteria for drought tolerance in Nicotiana tabacum. Can. J. Bot. 72, 1535-1540.

White, D.A., Battaglia, M., MacFarlane, C., Mummery, J.F., McGrath, J.F., Beadle, C.L., 2003. Selecting species for recharge management in Mediterranean south western Australia - some ecophysiological considerations. Plant Soil 257, 283-293.

Yeo, A., 1998. Molecular biology of salt tolerance in the context of whole-plant physiology. J. Exp. Bot. 49, 915-929.

Please cite this article in press as: Monreal, J.A. et al., Proline content of sugar beet storage roots: Response to water deficit and nitrogen fertilization at field conditions, Environmental and Experimental Botany (2006), doi:10.1016/j.envexpbot.2006.11.002 